\title{
Initiative for banning fireworks, in connection to a case report in the Mexican Institute of Ophthalmology
}

\section{Iniciativa de prohibición de los fuegos artificiales, a propósito de un caso, Instituto Mexicano de Oftalmología}

\author{
Aubert Quintanilla-Rivera*, Van Charles Lansingh, Ellery M. López-Star, José F. Pérez-Pérez, \\ Diana Álvarez-Melloni and Bethania López-Star \\ Instituto Mexicano de Oftalmología, Santiago de Querétaro, Qro., Mexico
}

\begin{abstract}
A 4-year-old patient, without relevant history,sustained a rocket explosion in the left eye a day before consultation (September 15), at midnight. He presented visual loss, bleeding and pain. Ocular examination showed a visual acuity in the right eye of count fingers at $3 \mathrm{~m}$, and in the left eye of no light perception. Right eye showed no eyelid alterations and left eye showed a superficial laceration in the inner canthus region of approximately $5 \mathrm{~cm} \times 5 \mathrm{~cm}$, eyelid edema and dried blood in the base of the eyelashes. Regarding anterior segment examination, the right eye showed no alterations and the left eye presented a collapsed eyeball with loss of architecture, diagnosing a Grade $E$ open globe injury. The ocular trauma score was of 1 , with a $74 \%$ probability of no light perception at 6 months. The patient underwent evisceration + medpor implant of the left eye 72 $h$ after the injury. The ocular prosthesis department is in charge of the patient's follow-up.
\end{abstract}

Key words: Eye injury. Fireworks. Epidemiology. Eye trauma. Firework-related injury. Injury prevention.

\section{Resumen}

Paciente de 4 años de edad, sin antecedentes de relevancia, recibe un día anterior a la consulta (15 de septiembre), a la media noche, una explosión de un cohete en el ojo izquierdo, que cursa con baja visual, sangrado y dolor. A la exploración oftalmológica presenta agudeza visual en el ojo derecho de contar dedos a 3 metros, en el ojo izquierdo, de no percepción de luz. En los anexos, el ojo derecho no presenta alteraciones, y el ojo izquierdo presenta laceración superficial en el canto interno de aproximadamente $5 \times 5 \mathrm{~cm}$, blefaroedema y tejido hemático en la base de las pestañas. En el segmento anterior, el ojo derecho presenta cornea transparente, cámara anterior formada, iris íntegro, pupila central normorreactiva, cristalino transparente, y el ojo izquierdo presenta estallamiento del globo ocular, con pérdida de su arquitectura. Se integra el diagnóstico de ojo izquierdo con trauma ocular abierto tipo ruptura, grado E, pupila no valorable, zona III. Tiene una puntuación de 1 en el Ocular Trauma Score, con pronóstico visual a 6 meses de no percepción de luz de un 74\%. Se sometió al paciente a evisceración e implante de Medpor del ojo izquierdo a las 72 h. Posteriormente, y hasta la fecha, ha sido manejado por el Departamento de Prótesis Ocular.

Palabras clave: Lesión ocular. Fuegos artificiales. Epidemiologia. Trauma ocular. Lesión por fuegos artificiales. Prevención de lesiones.

\section{Correspondence:}

*Aubert Quintanilla-Rivera

Colinas de Cimatario

Av. Estadio, s/n Del. Centro Sur

Date of reception: 06-03-2019

Date of acceptance: 05-04-2019

DOI: 10.24875/RMOE.M20000119
Available online: 01-07-2020 Rev Mex Oftalmol (Eng). 2020;94(4):163-165

www.rmo.com.mx 


\section{Introduction}

On May 7, 2016, the International Council of Ophthalmology (ICO) issued its position for the prohibition of the domestic use of fireworks in its document entitled: ICO Endorses Global Ban of Consumer Fireworks ${ }^{1}$. This document was later endorsed by the International Agency for the prevention of blindness. Likewise, the American Academy of Ophthalmology issued recommendations to avoid fireworks injuries ${ }^{2}$.

That is why, following the recommendations issued by these international agencies, the Mexican Institute of Ophthalmology joins the international efforts to ban the use of fireworks by the general population.

\section{Clinical case}

This is a 4-year-old male patient, brought to the Emergency Department of a public pediatric hospital after a firecracker explosion in the left eye in the midnight of September 15, 2018 when he and his grandmother were walking through the center of the city. There were other persons throwing firecrackers on the street.

The patient had visual loss, bleeding and pain (Figs. 1 and 2). Physical examination revealed a visual acuity of the left eye of no light perception. There was also a superficial laceration on the inner canthus of approximately $5 \mathrm{~cm}$, eyelid edema 2+ and remnants of hematic tissue on the eyelashes and the cul-de-sac. In the anterior segment of the left eye, we observed a ruptured eyeball. The patient was assessed by the ophthalmology department, and surgical management with evisceration of the left eye was indicated.

\section{Purpose}

To encourage ophthalmologists, as well as the Mexican Society of Ophthalmology and its state affiliates, to request the local and federal government to ban the use of fireworks by the general population, as a strategy to prevent blindness and visual impairment caused by injuries due to fireworks use.

\section{Background}

With the exception of Australia, where there is a ban on the use of fireworks, injuries due to fireworks are a global problem. These injuries affect producers, merchants, users and viewers of all ages ${ }^{2}$.

In the US, nearly half of those injured are minors, and from all eye injuries, a third cause blindness ${ }^{2,3}$. The US

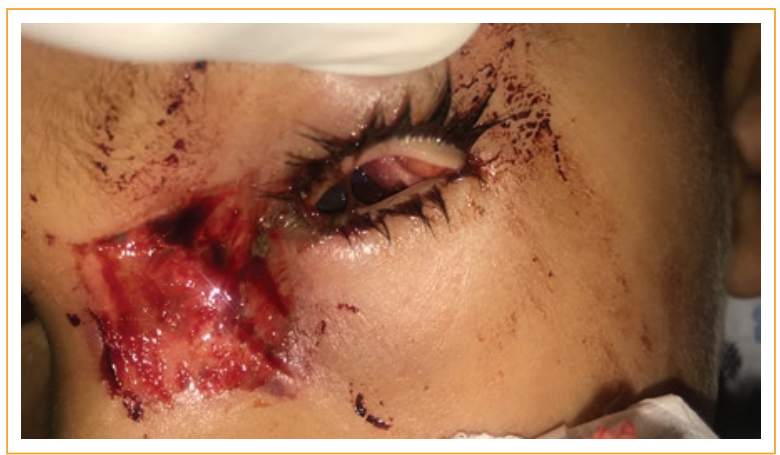

Figure 1. Clinical image of the patient's left eye.

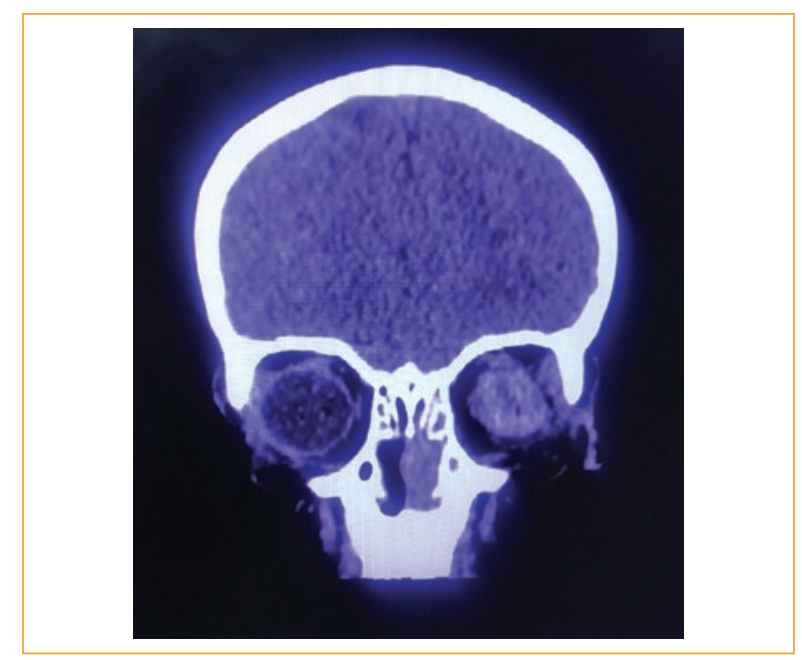

Figure 2. Computed tomography, coronal section showing collapse of the left eyeball.

Consumer Product Safety Commission reports that in 2014, there were 10,500 firework-related injuries, of which $19 \%$ were eye injuries ${ }^{4}$. Two-thirds of firework-related injuries attended in emergency rooms occurred during the summer holidays; a global trend has been reported on holidays ${ }^{5-9}$. A systematic review found that one out of six firework-related eye injuries resulted in severe visual loss ${ }^{10}$.

In India, one out of twelve minors with eye injuries due to fireworks treated in emergency rooms had unilateral blindness ${ }^{2}$. In South India, $71 \%$ of those injured by fireworks were spectators ${ }^{3}$.

In Germany, severe eye trauma caused by fireworks is reported more frequently in men, elderly patients, including spectators ${ }^{11}$.

In the United Kingdom, in a burn unit with injuries secondary to fireworks, it is also reported that $88 \%$ of injured patients are men and $51 \%$ are minors; $74 \%$ of injuries occurred in the period from October to November ${ }^{12}$. 
In 2016, Mexico made international headlines due to the explosion of a fireworks market in Tultepec, where there were 31 deaths and more than 50 injuries ${ }^{13}$. Despite this, in Mexico the reported evidence is minimal, although there are reports where firework- and gunpowder-related accidents (used specifically for the production of fireworks) cause $17 \%$ of burns due to direct contact with fire, and $11 \%$ of burns overall ${ }^{14}$.

In countries where there are regulations restricting the use of fireworks, an $87 \%$ decrease in eye injuries has been reported ${ }^{10}$. In Minnesota, USA, where a fireworks ban was lifted, a 100\% increase in annual firework-related injuries was reported ${ }^{15}$.

The American Academy of Ophthalmology recommends that people should attend professional fireworks events, instead of using domestic fireworks, and also urges the population not to allow minors to handle any kind of fireworks ${ }^{16}$.

\section{Conclusion}

Firework injuries are a global problem that affects thousands of people every year, especially during the holidays. Hundreds of cases of blindness and serious eye injuries can be avoided if changes are made to government regulations regarding fireworks.

The Instituto Mexicano de Oftalmología supports international efforts to ban fireworks, and urges the Mexican Society of Ophthalmology and its state affiliates to advocate for this cause.

\section{Funding}

No funding was received by any organization outside the Instituto Mexicano de Oftalmología.

\section{Conflicts of interest}

The authors declare there is no conflict of interest in this publication.

\section{Ethical disclosures}

Protection of human and animal subjects. The authors declare that no experiments were performed on humans or animals for this study.
Confidentiality of data. The authors declare that they have followed the protocols of their work center on the publication of patient data.

Right to privacy and informed consent. The authors have obtained the written informed consent of the patients or subjects mentioned in the article. The corresponding author is in possession of this document.

\section{References}

1. International Council of Ophthalmology ICO Endorses Global Ban of Consumer Fireworks, 2016. Disponible en: http://www.icoph.org/downloads/ICOPositionPaper-FireworksBan-May2016.pdf. Acceso: 28 de noviembre de 2018.

2. American Academy of Pediatrics Committee on Injury and Poison Prevention. FireworksRelated Injuries to Children. Pediatrics. 2001;108(1):190-91.

3. Elangovan S, Rajalakshmi AR, Velayutham V, Ranjit Prabhu D. An analysis of ocular firecracker injuries in five consecutive years during a festive season in a tertiary eye care hospital in South India. Expert Rev Ophthalmol. 2016;11(3):235-40.

4. Tu Y, Granados DV. 2014 Fireworks Annual Report. Fireworks-Related Deaths, Emergency Department-Treated Injuries, and Enforcement Activities During 2014. U.S. Consumer Product Safety Commission, 2015. Disponible en: http://www.cpsc.gov/Global/Research-and-Statistics/InjuryStatistics/Fuel-Lighters-and-Fireworks/Fireworks_Report_2014.pdf. Acceso: 28 de noviembre de 2018.

5. Deepa J, Swetha SP, Mittal R, Sheeja SJ, Padma P. Spectrum of ocular firework injuries in children: A 5-year retrospective study during a festive season in Southern India. India J Ophthalmol. 2015;63(11):843-6.

6. Mansouri MR, Mohammadi SF, Hatef E, Rahbari H, Khazanehdari MS, Zandi P, et al. The Persian Wednesday Eve Festival "Charshanbe-Soori" fireworks eye injuries: a case series. Ophthalmic Epidemiol. 2007; 14(1):17-24.

7. Adeoti $\mathrm{CO}$, Isawumi MA, Onakpoya $\mathrm{OH}$, Agbeleye DS. Banger-related ocular injuries during New Year festivities in Osogbo, SW Nigeria. Ethiop J Health Sci. 2015;25(2):185-88.

8. Kumar R, Puttanna M, Sriprakash KS, Sujatha Rathod BL, Prabhakaran VC. Firecracker eye injuries during Deepavali festival: A case series. Indian J Ophthalmol. 2010;58(2):157-59.

9. de Faber JT. Fireworks injuries treated by Dutch ophthalmologists New Year 2008/'09. [Article in Dutch]. Ned Tijdschr Geneeskd. 2009;153:A507.

10. Bijlsma WR, Stilma JS. Ocular firework trauma: a systematic review on incidence, severity, outcome and prevention. $\mathrm{Br} \mathrm{J}$ Ophthalmol. 2010; 94(12):1586-91.

11. Unterlauft JD, Wiedemann P, Meier P. Bulbustraumata durch Feuerwerkskörper von 2005 bis 2013 (Firework - Related Eye Trauma from 2005 to 2013, article in German). Klin Monatsbl Augenheilkd. 2014;231:915-920.

12. Nizamoglu M, Frew Q, Tan A, Band H, Band B, Barnes D, et al. The ten-year experience of firework injuries treated at a uk regional burns \& plastic surgery unit. Ann Burns Fire Disasters. 2018:31(1):13-6.

13. Villegas, Paulina. Explosión en mercado de cohetes en México causa más de 30 muertes. The New York Times ES. Disponible en: https://www. nytimes.com/es/2016/12/21/explosion-en-mercado-de-cohetes-en-mexico-causa-mas-de-20-muertes/. Acceso: 28 de noviembre de 2018.

14. Evite accidentes con fuegos artificiales. PROFECO. Disponible en: https:// www.profeco.gob.mx/encuesta/brujula/bruj_2005/pdf05/Evite\%20accidentes\%20con\%20fuegos\%20artificiales.pdf. Acceso: 28 de noviembre de 2018.

15. Roesler JS, Day H. Sparklers, smoke bombs, and snakes, oh my! Effect of legislation on fireworks-related injuries in Minnesota, 1999-2005. Minn Med. 2007;90(7):46-7.

16. American Academy of Ophthalmology (AAO). American Academy of Ophthalmology Urges Use of Protective Eyewear When Using Consumer Fireworks This Fourth of July. June 22, 2015. Disponible en: http://www. aao.org/newsroom/news-releases/detail/fireworks-eye-injury-survey-2015-press-release. Acceso: 4 de abril de 2016. 